\section{THE AFFINITIES OF SCHIZOTRYPANUM.}

IN a recent number of the Archiv fïr Protistenkunde (vol. xx., p. 36I), Dr. M. Hartmann makes an important addition to our knowledge of Schizotrypanum cruzi, the trypanosome of human beings discovered by Chagas in Brazil (see Nature, August 4, 1910). Chagas described a process of multiple fission ("schizogony"), taking place in the lung capillaries, of forms not enclosed in cells (NATURE, l.c., p. 143, Fig. 2, $b-e)$. In addition to this type of multiplication, Hartmann finds another process of schizogony within hypertrophied endothelial cells of the lung, as a result of which the cell contains some twenty or more small, pear-shaped organisms, each with a distinct kinetonucleus and trophonucleus, but no flagellum. The chief interest of this discovery lies in the very great resemblance of these intracellular forms of Schizotrypanum to those of Leishmania donovani, the parasite of Kala Azar; in fact, anyone, looking at the figure given by Hartmann, might suppose that it represented a preparation of Leishmania. Similar forms are stated to have been found in the heartmusculature and brain of human beings that have died from "Schizotrypanosomiasis" (sic), sit venia verbo!

In view of the resemblance, in certain phases, between Schizotrypanum and Leishmania made known by Hartmann, attention may be directed to some remarks by Donovan, one of the discoverers of the parasite of Kala Azar, in the "Annual Report and Statistics of the Government General Hospital, Madras," for the year 1908 (published 1909), p. 3I. 'Donovan casts doubt on the view advanced originally by Rogers, and further supported by Patton, that the parasite of Kala Azar is transmitted by the bed-bug; and gives reasons for believing that another bug, Conorhinus rubrofasciatus, is the insect which propagates the disease. It would be remarkable if both Leishmania and Schizotrypanum proved to be transmitted by species of the genus Conorhinus, the one in India, the other in Brazil. The etiology of Kala Azar is a problem which calls urgently for investigation.

E. A. M.

\section{THE ORGANISATION OF TECHNICAL} EDUCATION AND RESËRCH. ${ }^{1}$

VERY few words of mine are needed to emphasise the interest and the importance of this annually recurring ceremonial at which the varied educational work of the City and Guilds Institute receives recognition, well-merited recognition, from successive Lord Mayors.

We gather from the brief résumé of the work which has been read by Sir J. Watney that the various agencies combined under the control of the institute continue to flourish, the students increase in number, their work rises in quality, and the importance of the institution grows greater year by year.

The City and Guilds Central Technical College completed its twenty-fifth session in July, and now has at work 412 students. In the twenty-five years, 1512 students have taken the complete course and 1066 have been awarded the diploma. Out of 306 internal degrees conferred in the faculty of engineering in London University, I57 have been obtained by students of the college; and the percentage in honours has been a high one, 56 per cent. first class, 42 per cent. pass.

The year has been marked in that the relations with the Imperial Technical College have been made definite by the appointment of a delegacy, under the immediate control of which the City and Guilds College is placed, and which contains representatives of the Imperial College, the Institute, and the Goldsmiths' Company. The delegacy, I am informed, held their first meeting last month.

I will not attempt to review in like manner the year's results for the other branches of the institute. Numbers of young men-some of them not so young now-owe their success in life to the training received at the Finsbury Technical College from the inspiring teaching of its accomplished head, Prof. S. P. Thompson, and his able staff; and here I should like to thank Prof. Thompson

1 Address delivered at the prize distribution of the City and Guilds of London Institute on February 17 , by Dr. R. T. Glazebrook, F.R.S.

NO. 2157 , VOL. 86$]$ for his recent brilliant addition to our scientific biographies. Had he done nothing else, and this is far from being the case, his life of Kelvin would have left future generations deep in his debt.

I know less, perhaps, of the other work of the institute, but I know enough to be grateful to the committee and its officers for the large contribution to the advance of knowledge they have made by their efforts in the past.

The choice of a subject for an address of this kind is not quite easy, and yet it ought not to be very difficult for a man whose life is now bound up with the business of science to find a theme on which to speak to an audience in this centre of industry and commerce-the connection of science and industry is an obvious, perhaps even a hackneyed, one. Nevertheless, I am going to trespass on your patience with some aspects of the question as they appear to me.

Not many years ago it would have been said that the connection was a slight one. Science dwelt in a realm apart from industry and commerce; her votaries were men who sought the truth without a thought of the gain the search might bring to humanity, or the wealth it might discover for the seeker.

It was enough for them to arrive at some new law, to roll back a little space the veil that shrouds the mysteries of Nature and to penetrate her shrine. Long may there be such men; the humbler students of science, those who try to interpret her teachings for the good of men, could advance but little without the torch of truth carried by these their leaders. But it is realised now that there are many ways in which science can further industry. Let us look at two of these.

It is sometimes said our German cousins are more scientific than ourselves, and that this is the reason of their great material progress during the past fifty years. In a sense this is true; not that they have made greater discoveries or have contributed more to the sum of human knowledge, but they did realise at an earlier date than we the value of science as a factor in industrial and commercial progress. They showed their appreciation of its importance by the establishment, in the first place, of technical colleges and universities where students could be trained to apply science to the needs of daily life, and in the second of institutions like the Reichsanstalt and the Versuchsanstalt, where researches on matters bearing on the application of science to industry could be carried out on a fitting scale.

The colleges and universities which in the past twentyfive years have grown up in our cities show that we have begun to appreciate the need and to make some notable endeavours to supply it. For the success of these endeavours, no small debt is due to those great City Guilds which, with well-judged munificence, have devoted such large funds to the work of education, not only here in London, but also in the ancient universities and in many other parts of the country.

This gathering to-night, with its long list of prizes and awards, is a speaking testimony to the value of their work in London. The wise leaders of the City Guilds realised that by the work of education they could best advance the welfare of our country and carry on under present conditions the task which previously they performed by means of the apprenticeship system.

Let us look into this educational work in its modern form. It received a notable impulse a few years ago by the establishment of the Imperial College of Science and Technology: That college was founded with a very definite purpose- to afford to English students the opportunity for the highest study and research in any branch of science bearing on industry. Two methods at least were open to the founders, and of these they chose the more difficult. It is our English plan to let our old institutions develop gradually, so as to meet new needs. The committee responsible for founding the Imperial College might have established something quite new; they decided rather to combine three great agencies existing at South Kensington into one, thus coordinating work already in progress, while maintaining the individuality of the constituent institutions. The Royal College of Science, the Royal School of Mines, and the City and Guilds Technical College still exist, but, combined as they are under one governing body of the Imperial College, their 
influence on education and on progress, great as it has been in the past, must be multiplied manifold.

Time is necessary to solve the many problems that arise, but a visit to South Kensington, where, by the generosity of Messrs. Wernher, Beit and Co., and the trustees of the Bessemer fund, splendid new buildings are rising rapidly for the Royal School of Mines, and by the munificence of the Goldsmiths' Company the engineering laboratories of the central institution are being so greatly enlarged, is enough to show some of the first-fruits of the work.

The method which has been adopted for controlling the work of the Central College by means of a delegacy representing the Imperial College, the City and Guilds Institute, and the Goldsmiths' Company, is full of promise, and the path whereby the whole can develop into the great institution planned by its founders seems clear.

Much is still necessary before that development can be complete. In the first place, we must encourage research. The Central Technical College has a splendid record among its professors-Henrici, Unwin, Ayrton, Armstrong. Nor will the work of the younger men-Dalby and Mather-be less distinguished in the future. Still, more remains to be done in the way of post-graduate study and students' research. I do not overlook the notable efforts made lately in connection with the railway engineering course, but I would urge those in whose hands control lies so to organise the teaching that men, professors, or students who have the power to carry on research, should be free to use it. You cannot successfully command a professor to make discoveries. You can arrange his surroundings so that the power that is in him should have full opportunities of action.

Secondly, we must not attempt in the Imperial College to do elementary work which can be done equally well elsewhere. The Central Technical College has always done rightly in selecting its students with care. Its success, and the fact that the students now number as many as the college can hold, increase its power of selection; the conditions of entrance may be raised gradually; they are still very low compared with the great German technical schools; and thus the whole character of the work may be improved.

Thirdly, the Imperial College must not remain isolated. The agencies at work in London applying science to the wants of industry, not merely teaching the rudiments, but advancing the boundaries between the known and unknown, are numerous; they include the University Colleges, with their distinguished professors and their large classes of students; the polytechnics and technical schools, where, day and night, educational work of the highest value is being eagerly pursued.

Is it impossible to conceive some scheme by which the labours of all these agencies for technical instruction should be coordinated and linked up with the work of the Imperial College as a centre, to which, to repeat what I said in an address I delivered to the Association of Technical Institutions, students only of proved capacity were admitted, where the staff and students were free to conduct original investigations, and through these to learn new truths, where scholars and prizemen from the various technical institutions of London were collected, and where the teachers in the polytechnics and other colleges were freely welcomed to carry out their researches and to advance learning?

In close connection with this there should be a number of colleges organised so as to provide teaching for the less advanced stages of the course, selected with due regard to geographical conditions.

Beyond these would come those polytechnics which were engaged chiefly in evening classes for the worker, each, if possible, with one special department organised so as to provide teaching and means for research of an advanced character, linked up to the central institution, the Imperial College, in such a way that the teachers felt a common interest in promoting the welfare of that institution, and turned naturally to its professors as their leaders in the search for truth.

There is one essential more. This group of institutions -the Imperial Technical College and its associated colleges-must possess the power itself of granting No. 2157 , VOL. 86 ] degrees in technological science to its students who have gone through its course and passed the proper tests without reference to any external academic body. To secure this may be difficult, but it must be done. In Germany it was recognised some years ago that the degree courses of the older universities did not afford the student of technology the training he required, and new universities -technological universities they are called, though the phrase may be a misnomer-have been established in many of the great centres of industry.

Here in England, outside London and the old universities, our course has been different. The new universities in Manchester, Liverpool, Birmingham, and elsewhere, have each a faculty of technology along with those of arts and science, law and medicine, and their constitution allows them to do this with success, for in no case is the control in the hands of an academic body-an unwieldy Senate representative of all and every conflicting interest that can conceivably be brought in. It rests with a compact council, consisting mainly of business men, keen to raise the standard of education in their cities because they realise that on that progress turns.

It may be possible to reorganise London University as an assemblage of faculties, each practically independent in its own sphere, each controlled by its council, a small body of men containing some few representatives of the teaching staff. This council, within the scheme, would be the supreme body of the faculty; subordinate to it would be the general board of studies, representing all the teachers, and the special boards dealing with the various subjects of study in the faculty. Each faculty should award its own degrees and be free to determine, with the lines of the general scheme, the conditions under which those degrees should be granted.

There would need to be advisory committees of representatives of several faculties for work in which more than one faculty was concerned, and a small body, independent of the faculties, to settle disputes which might arise.

Under such a scheme the Imperial College would become the centre of the Technological University for London, and then for the Empire, a body like its governing body, but modified so as to include representatives of the other institutions which would form with it the technological side of the University in London, would become the council of that faculty; the teachers in the various subjects represented in the faculty would form the various special boards of studies, and representatives of these special boards would become the general board of studies of the faculty.

Whether this be a possible scheme or not it is not for me to say, but I would venture to put forward three propositions :-

(i) That a combination of the technological depart ments of existing institutions and schools into an independent technological faculty is necessary.

(2) That in such a faculty a definite value should be given to technical education in each London school.

(3) That the technological faculty should confer degrees under conditions to be laid down by the faculty.

I am aware I have wandered into debatable ground. I trust I have not erred beyond forgiveness in so doing. The task before Sir Alfred Keogh, the rector of the Imperial College, in bringing to success some scheme such as this is no easy one. It will lighten it immensely if you can assure him that in his task he has your own support and that of the men to whose active help the success of the City and Guilds Institute is so largely due.

You may rest assured that in this way you are assisting in no small degree to render the advances of science available for the promotion of the best interests of our nation, in strengthening our position in the world, and in carrying on that great work of education in which the City Guilds have taken so admirable a share.

But there is another aspect of my subject, the relation of science to industry, for which I have left too little time. A second way in which science may help industry is, as I have said, by the establishment of institutions where scientific questions bearing on industry may be studied.

The National Physical Laboratory is such a place, and when the chairman of the committee invited me to speak 
here to-night, he said he wished me to tell you something of the work of the laboratory.

It is a big work, for the subject is big. The laboratory was founded some ten years since as a public institution for standardising and verifying instruments, for testing materials, and for the determination of physical constants.

Its staff now numbers about 140 persons, its expenditure during the past year was more than $28,000 l$, and towards defraying that expenditure more than $15,000 l$. was received in fees for work done.

During the past eleven years, if we exclude the aëronautical work, $49,000 l$. has been contributed from public funds towards capital expenditure, while $54,000 l$. has been raised from private sources. In the same period, the annual grants from the Treasury for working expenses have been $57,750 l$., while the receipts from fees, private donations, and subscriptions have come to $105,380 l$.

Instruments of all kinds were examined, among them in 1910 were 27,500 thermometers, 4000 telescopes, 1600 binoculars, electrical apparatus, measuring apparatus, optical appliances, photographic lenses, opticians' testing lenses (these numbered 5000), and taximeters. The value of the instruments sent for test is nearly roool. for each working day of the year.

Nor is this half of the work. Researches of all kinds of interest to industry and manufactures are in progress. Papers have been communicated to engineering and scientific societies which have aided in the solution of many important technical problems, and investigations are now in progress which will help still further.

The laboratory is controlled by a committee appointed by the Royal Society and representing the great scientific and technical societies, and the general scheme of research is approved by them. But besides these public investigations, each day brings us inquiries from private firms and manufacturers as to matters on which they want our help or our advice.

The home of the laboratory is at Teddington, in Bushy Park, and there, round the old Royal residence, Bushy House, the modern buildings needed for the work are being slowly and painfully raised. For some of these funds have been provided by the Government; others we owe to private generosity to men like Sir Andrew Noble. Sir John Brunner, Mr. Yarrow, who has just built for us an experimental tank for naval research at a cost of 20,00ol., Sir Julius Wernher, whose generous gift of $10,000 l$. has rendered it possible to commence the erection of a laboratory for metallurgical research, or to those of the city companies, the Goldsmiths', the Drapers', and others, who have listened to our appeal.

Meanwhile, we live from hand to mouth; the deficit this last year, on a total expenditure of nearly $30,000 l$., was about $200 l$, and now we are appealing for funds to build an optical laboratory, a library, and reading room, with other offices for our work.

We shall not appeal, I know, in vain, because Englishmen at last are realising that organised scientific effort is an essential factor in the country's progress; you students who in the various colleges of this institute have learnt something of what science is, what scientific effort can do, in time some of you will become the leaders of industrv. See to it, then, that those institutions to the work of which your success is due are made ever more efficient through your generous support.

\section{PROGRESS REPORT OF THE CARNEGIE} INSTITUTION OF WASHINGTON.

THE ninth annual report of the Carnegie Institution of Washington, in which the numerous activities of the institution during 1910 are described, is now available. The volume runs to 275 pages, and contains also five wellreproduced plates. As usual, the report includes the articles of incorporation of the institution, its bye-laws, the minutes of the meeting of the Board of Trustees, the report of the president of the institution, that of the executive committee, as well as detailed reports on the numerous investigations and projects of the institution.

The president's report presents in order a review of the work of administration of the institution, a résume of the investigations carried out during the year, and a summary of the publications authorised and issued during the rear ending October $3 I$, I910. The subjoined extracts. from the report will serve to illustrate the increasing importance of the research work undertaken under the auspices of the institution.

\section{Work of Administration.}

The more noteworthy events in the history of the institution during the past year are the dedication, in December, I909, of the Administration Building; the inauguration at that time of an annual series of semipopular lectures explanatory of the researches of the institution; the inauguration on the same occasion of a series of periodical exhibits of the work accomplished by the departments of investigation and the divisions of publication and administration; the successful completion of the first voyage (of 8000 miles) of the non-magnetic ship Carnegie, and the beginning of a second cruise, which is expected to require three years, by this novel craft; and the fourth conference of the International Solar Union, held at the Solar Observatory of the institution on Mount Wilson, California, from August 29 to September 4, I9I0.

It appears that since its organisation in 1902 upwards of twelve hundred individuals have contributed in one way or another to the promotion of the researches and the publications undertaken by the institution. During each of the past five years about five hundred individuals have thus collaborated. Ten independent departments of research and the divisions of publication and administration, each with its staff and assistants, have been organised and established within the institution itself. In addition to these larger departments of work, numerous special researches, in aid of which upwards of seven hundred grants have been made, have been carried on by research associates and other individual investigators. For the departments of research, two astronomical observatories, five laboratories, and a non-magnetic ship have been built and equipped.

The following list shows the departments of investigation to which the larger grants were made by the trustees, and the amounts allotted from those grants by the executive committee during the year:-

\begin{tabular}{llllr} 
Department of Botanical Research & $\ldots$ & \multicolumn{1}{c}{} \\
Department of Experimental Evolution & $\ldots$ & 8,946 \\
Department of Economics and Sociology $\ldots$ & 2,194 \\
Geophysical Laboratory & $\ldots$ & $\ldots$ & $\ldots$ & 10,204 \\
Department of Historical Research & $\ldots$ & 4,540 \\
Department of Marine Biology & $\ldots$ & $\ldots$ & 5,414 \\
Department of Meridian Astrometry & $\ldots$ & 7,131 \\
Nutrition Laboratory & $\ldots$ & $\ldots$ & $\ldots$ & 5,276 \\
Division of Publications & $\ldots$ & $\ldots$ & $\ldots$ & 1,800 \\
Solar Observatory $\ldots$ & $\ldots$ & $\ldots$ & $\ldots$ & 23,144 \\
Department of Terrestrial Magnetism & $\ldots$ & 15,384 \\
\hline
\end{tabular}

Résumé of Investigations of the Year.

Work in the ten specially organised departments of research in the institution has gone forward during the year with increasing vigour and with increasing productivity. But while the existing status of departmental affairs is in general highly satisfactory, it appears essential again to direct attention to the fact that with present income and current economic conditions no further expansion of departmental appropriations can be expected. It may be neces. sary, on the contrary, to curtail research in the depart ments in order to keep the aggregate expense of the institution within income. It need not follow, however, that this prospective diminution in financial outlay will cause a corresponding diminution of productivity, for work of investigation, like work along other novel lines, is usually most costly in the preliminary stages.

The headquarters of the Department of Botanical Research are located in a desert area where the facts of plant life are exhibited, in general, in their simplest, though often extreme and highly specialised, relations. During the year the director of the department has continued his investigations on the water-balance of succulent plants, on the conditions of vegetable parasitism, on the variability in plant species induced by chemical treatment of their seeds, and on the influences of climate on plant organisms. 